\section{Marquette University \\ e-Publications@Marquette}

Arabic Languages and Literatures

Languages, Literatures and Culture Faculty

Research and Publications

$12-6-2018$

\title{
Muslim Women in the Diaspora: Shaping Lives and Negotiating Their Marriages
}

Enaya Othman

Marquette University, enaya.othman@marquette.edu

Follow this and additional works at: https://epublications.marquette.edu/arabic

\section{Recommended Citation}

Othman, Enaya, "Muslim Women in the Diaspora: Shaping Lives and Negotiating Their Marriages" (2018). Arabic Languages and Literatures. 6.

https://epublications.marquette.edu/arabic/6 


\title{
Marquette University
}

\section{e-Publications@Marquette}

\section{Languages, Literatures and Culture Faculty Research and Publications/College of Arts and Sciences}

This paper is NOT THE PUBLISHED VERSION; but the author's final, peer-reviewed manuscript. The published version may be accessed by following the link in the citation below.

World of Diasporas: Different Perceptions on the Concept of Diaspora, Chapter 10 (2018): 92-101. Publisher link. This article is (C) Brill and permission has been granted for this version to appear in $\underline{\mathrm{e}}-$ Publications@Marquette. Brill does not grant permission for this article to be further copied/distributed or hosted elsewhere without the express permission from Brill.

\section{Muslim Women in the Diaspora: Shaping Lives and Negotiating Their Marriages}

\author{
Enaya Hammad Othman
}

This study focuses on two distinctive periods: the 1950s-1980s and 1990s-2000s. As a point of clarification, I am using the term 'First Generation' to apply to immigrants who were born outside the United States, and 'Second Generation' for their American- born children. This study utilizes at least 60 interviews conducted during the last six years among Muslim immigrants and their offspring in the greater Milwaukee region. 40 of these interviews are with women of Palestinian descent. ${ }^{1}$ In addition to scholarly research, community members' photographs, and focus- group discussion, I use my personal observations as a member of the Arab and Muslim community in Milwaukee.

The interviewees were selected based on three groupings: immigrants were selected based on their time of immigration; second- generation Palestinian-Americans were selected based on one of two age groups: over 30 years old-with parents who immigrated between the 1950s and 1980s, and 22 to 29 years old - a group for the children of parents who immigrated since the late 1980s. Interviewees are given pseudonyms.

In Milwaukee, Palestinian Muslim women went through different kinds of marriage processes depending on the period their parents arrived in the United States, their education level, availability of compatible Palestinian spouses, and socialization outside their parents' national origins. Many second-generation Palestinians preferred to marry a partner from the same cultural background if a compatible potential spouse was available. This 
preference seems mainly because of their special case as a displaced group living in diaspora and longing for their own independent nation-state.

\section{Muslim Communities in Milwaukee}

Few Muslim migrants began to settle in Milwaukee before WWII. Most who came after the war were Arabs and reflected the national origins of their Arab Christian counterparts who arrived in the late nineteenth and early twentieth centuries. Until the 1980s, Palestinians constituted the majority of Muslim immigrants living in Milwaukee. They immigrated primarily as a result of the creation of the Israeli State in 1948 and the Israeli occupation in 1967.

Palestinian immigrants were politically and culturally active. They formed organizations that integrated the community into the American political and economic processes, but also agitated for their national homeland and advocated for Arab culture. ${ }^{2}$ After the 1980s, the political and economic climates in majority- Muslim countries lead to the arrival of an increased number of immigrants who saw themselves as Muslims first. These immigrants came from South Asia and some Arab countries and affected the way Arab-Muslim communities in the United States perceived themselves in relation to their ethnicity and religion. This trend was part of a global Islamic revival movement fueled by an increase in religious education and spread with advancements in communication. ${ }^{3}$

A host of factors aided this Islamic revival movement, including the Arab-Israeli War in 1967 and the Israeli occupation of Palestinian territories. These events resulted in feelings of despair and betrayal among people across Arab countries, which caused them to question the legitimacy of their national governments. Other events, such as the civil war in Lebanon between 1976 and 1990, the Iranian Revolution of 1979, the Palestinian uprising in 1987, and the Gulf War in 1990, strengthened the Islamic movements in the Arab world. ${ }^{4}$

These emerged as possible replacements for the national secularist movements that failed to solve a myriad of political, social, and economic problems. This Islamic revival stimulated the establishment of Islamic institutions that became centers of social activities. The religious identity of the new wave of immigrants took precedence over their national and ethnic identities. ${ }^{5}$ These new immigrants played a major role in emphasizing the need for Arab- American communities to establish Muslim institutions in order to preserve their faith. These efforts led to the establishment of the Islamic Society of Milwaukee (ism) in 1980, which now functions as a major religious and cultural center. ${ }^{6}$

In the last two decades, Milwaukee also became the destination of a significant number of Muslim immigrants from around the globe. There are an increasing number of mosques and Islamic centres in different areas in the Greater Milwaukee Region. These include the ism Main Center (and its K- 12 school) and its two new Mosques: ism Brookfield West and ism University East. ${ }^{7}$ In addition, a number of other Sunni mosques and centres have been established throughout the area. ${ }^{8}$ There are differing statistics on the exact number, but a rough estimate suggests that there are between 15,000- 20,000 Muslims in the Greater Milwaukee area. ${ }^{9}$

\section{First- Group Palestinian Immigrants and Their Offspring (1950s- 1980s)}

During the period between the 1950s and 1980s, the Milwaukee Muslim community was composed mainly of Arab immigrants who held deeply ingrained nationalist ideologies. ${ }^{10}$ Moreover, Muslim women of this wave came mainly as young brides joining their husbands who had previously lived in the United States. ${ }^{11}$ Some women migrated along with their families. Few Arab and Muslim women migrated alone. ${ }^{12}$

Most of the Milwaukee Palestinian women who arrived in the 1950s and 1970s had high school diplomas or less. Their husbands usually had some form of higher education. ${ }^{13}$ This trend parallels the traditional American 
families of the 1950s when the husbands typically had more education than their wives. ${ }^{14}$ Usually the age of marriage ranged from 16 to 21 years old. The 15 interviewees who migrated between the 1950s and 1980s came mainly from the Ramallah region. ${ }^{15}$ Most have either elementary or secondary education and four have high school diplomas. Only one among them has a college degree.

Each of these women had a unique story about her marriage process, but arranged marriages and early marriage age were common features. Their marriages also tended to be endogamous, meaning that their spouse was from within the same religious, ethnic, and regional groups. Sometimes these marriages were even consanguineous. ${ }^{16}$ For example, five of interviewees were married to a relative of their mother or father.

Typically in an arranged marriage, as most interviewees explained, several steps would be taken leading to the wedding. The first is the Tulba which is when the groom and his family made a formal visit to the bride's house to ask for her hand in marriage. Tulba allowed the couple to learn more about each other, usually with a family member present. When the couple and their families have agreed upon the marriage, they will move forward with the legal marriage contract, katb kitab. This is done before the wedding ceremony takes place- anywhere from a week after the Tulba to a few days before the wedding ceremony. A couple of nights before the wedding ceremony, a Henna celebration is held for the bride and the groom along with friends and family in which they have the opportunity to dress in traditional clothing and receive henna tattoos. Finally, the wedding ceremony is held. There is usually a dinner, music, and dancing.

During this period, the second generation of this group also tended to marry spouses of their parents' nationality. Their marriages were usually arranged but they had a greater role than their parents' generation in choosing their potential spouse. Usually a period of chaperoned dating would take place. The small size and the composition of the community were limiting factors for the bride, who typically sought grooms who were Palestinian with higher education.

During this period, families from the same towns stayed in touch with each other through local and national events. These organizations had cultural and political functions, and aimed to keep immigrants from these areas connected. They also encouraged the second generation to marry from within their own group. ${ }^{17}$

Sometimes young males would meet a girl at a family or community function; other times, the mother of the groom would look for suitable girls for her son by asking relatives and friends living in other cities in America. When a suitable girl was located, a background check would take place (on the potential bride's behaviour, her looks, educational level, and family reputation) and if it came back positive, the groom's family would make a visit to ask for the girl's hand in marriage. The bride's family also did their own background check, and then the potential spouses met to decide if they agree to marry.

A significant number of the children of this group were accustomed to marry Palestinians either born in the United States or Palestine. Sabreen, born in the United States confirmed, 'It is nice to be from the same village and same cultural background. ${ }^{18}$ Usually the process for those marrying Palestinians living abroad is that the parents take their daughter to marry her to suitors from their original city or town. Dana, Lena, and Randa, born and raised in Milwaukee, went to visit Palestine with their parents and got married there at the ages of 20, 21, and 17 respectively. They then applied for spouse immigration visas and brought their husbands to live in the United States.

Randa, however, has three younger sisters who all finished college. Her sisters' marriages were not arranged. Each of her younger sisters met their husbands in college in Milwaukee. Two of them married Palestinians, but one married a Moroccan. Randa and her sisters exemplify a notable division within American born Palestinians: the divide between older and younger siblings. Older siblings tended to marry in the same national group and in significant numbers to foreign- born spouses- usually from the same area in Palestine as their parents. Their 
educational levels vary: very few have less than a high school education, some had a few years of college. Among the group with less- than a high school education, some finished their diplomas after they got marriedas did Randa herself.

The group of younger siblings, as exemplified by Randa's sisters, tend to have more choices and this seems to be connected with the growth of the Muslim community in the 1990s. As the Muslim community became larger and more diverse, parents tended to loosen their expectations of marrying their daughters to Palestinians.

\section{Second- Group Immigrants and Their Second Generation (1990s- 2000s)}

This group of Palestinian immigrants arrived at a time when Islamic institutions functioned as spaces for community cultural activities. The Muslim community is larger and more diverse than in the previous period. Newcomers from South Asia, Morocco, and other Arab countries changed the demographic composition of Muslim communities in Milwaukee. ${ }^{19}$

Among Muslim women during this period, it is clear that their level of education and the education of their second generation were major indicators of the increase in their marriage negotiation power. The increased size and diversity of the community allowed for interactions among Muslims from different ethnic and national backgrounds. This interaction tended to fuse community members around one common shared religious identity. This religious identity 'legitimises increased individual control of marriage decisions, ${ }^{20}$ enabling the second generation to utilize this identity as a negotiating tool for their marriages.

Most Palestinian women who migrated in the 1980s and 1990s came with at least high school or college degrees. The marriage age was between 18- 24 years old. They came mainly from the Ramallah region. ${ }^{21}$ Among the ten interviewees who migrated during this period, four came from the Ramallah region with four-year college degrees, two with high school diplomas, two from Kuwait with some college education, and two from Jordan with high school diplomas. Half of these interviewees went back to school after migration either for undergraduate or graduate degrees. All of them married either before migration or came as engaged and married in the United States. Among these, five interviewees have the same level of education as their husbands, three have less education, and two interviewees have higher education than their husbands. Their marriage processes varied; those with college degrees met their husbands in college and their marriages were not arranged. These women then went through the rest of the arranged marriage process of back ground check, Tulba and Katb Kitab.

The second generation of these immigrants shows a deviation in their marriage behaviour from both their parents and the older children of immigrants from the first group. They usually tended to finish college before marriage. Their educations, interactions with a diverse Muslim community, and the limited number of qualified potential Palestinian spouses were the three major reasons for their marriages outside their national group. When negotiating their marriages, they used their identification as Muslim and American, not as Palestinian to get their parents' consent. Moreover, few among them preferred to marry Palestinians who were born and raised in Palestine even if they are educated, as they see them as culturally incompatible.

Interestingly, most of these women explained that they do prefer to marry second generation Palestinians that meet their criteria. Bisan explained that her husband 'had to ask (my father) for my hand' to get her parents' consent. Her father has to 'make sure he qualified for (his) criteria' of being educated, Palestinian, and Muslim. ${ }^{22}$

For this generation as a whole, though, religion is the determining factor and should come before their Parents' culture. Fatima explains the roles religion and culture play in her life:

Most of my morals and things like that stem from my religion and not really from my culture, so, I really do identify $100 \%$ as Palestinian, I don't think that it influenced me more than my religion. But, it just 
really effects, my activities and everything revolve around it (culture), but it does really identify my qualities and morals and stuff as a person. So, it's part of my identity, but it's not something that really defines me, more than, my religion does. ${ }^{23}$

The meaning of marriage among first and second- generation Muslim women varies in its priority depending on level of education and career goals. Most of the interviewees expressed the importance of marriage regardless of their generation and level of education. They expressed that marriage is 'a religious duty, which is always put as a safeguard for a person and it's also a social necessity.' ${ }^{24}$ It is an obligation for Muslims to be fulfilled at some point because it constitutes 'half of your deen (religion). ${ }^{.25}$

Among this group, education and religiosity took precedence over Parents' cultural origins when selecting a marriage partner. Usually intermarriages indicate the hardship parents face in maintaining cultural consistency versus the subsequent generation's increasing demand for matching religious values. ${ }^{26}$ Most of our interviewees who married outside their group indicated that it took a good deal of convincing to get their parents' permission to bless their marriage decision.

Fear of not finding the right match played an important role in marriages outside a national group. Fatima met her husband at the local religious centre in 2009 and married him in 2015. It took her a few years to get her family to accept him because he was not Palestinian. After she got engaged, members of her Palestinian community reacted and questioned her decision to marry a Syrian.

For Fatima herself, a potential groom's parents' national origin should not be the primary identification. This view presented difficulties among her Palestinian community, as 'people wouldn't identify him as an engineer, or they wouldn't identify him as a Muslim, or as an Arab. But the first thing that they would mention was his [Syrian] culture.' She confidently explained to them that her decision 'wasn't like haram (forbidden in Islam) or $a y b$ (shameful).' She confirmed that her friends, who are mainly second-generation Muslim women, 'cared more about how he looked and what he did for a living' than his national origins. However, Fatima's identity as a Palestinian- American is still important to her. She explained her mixed feelings:

Omar was the guy that fit all of my dad's expectations except for one, which was that he was not Palestinian. And so, when Omar came to ask for me, I instantly knew that it was gonna be a problem, but I also knew that he fits all other criteria so it wasn't bad. Um, it wasn't really outside of the expectations of my dad - I mean me and my dad both have the same expectations, and to be $100 \%$ honest, I would want - just because of what's going on overseas, I would want my children to be $100 \%$ Palestinian. I mean it's the dream. It's what I would want - I want - I want that for my family and for just the future of Palestinian people. ... But I mean if I sat around all day and waited for somebody who was compatible with me and who met all the expectations that I had, all the expectations my dad had, and who was Palestinian, I would be- I would never get married. ${ }^{27}$

Second generation Palestinian women's interactions with other Muslim and non- Muslim communities impacted their identity formation, their perception of their rights and the manner in which they assert those rights. This has, in turn, affected changes in marriage patterns. This brings in changes in marriage patterns in second generation immigrants. As the cultural theorist Stuart Hall claims, 'diasporic' identities are reflections of living 'in translation' as individuals 'must learn to inhabit two identities, to speak two cultural languages, to translate and negotiate between them. ${ }^{28}$ This negotiation and translation of multiple identities enables Palestinian women to develop a broader sense of belonging that crosses national, ethnic, and racial lines. ${ }^{29}$

\section{Bibliography}

Ahmad, Leila. The Veil's Resurgence, from the Middle East to America. New Haven: Yale University Press, 2011. 
Al- Johar, D. 'Muslim m Marriages in America: Reflecting New Identities.' The Muslim World, 95, (2005): 557574.

Anthias, Floya. 'Evaluating 'Diaspora': Beyond Ethnicity?' Sociology 32 (1998): 553- 580.

Atta, O. Muslims in Milwaukee: A Brief History. ISM, Islamic Society of Milwaukee: 25 Years of Service 19822007. Milwaukee, WI: ism, printed booklet for the 25th anniversary, 2007.

Bangstad, S. 'When Muslims Marry non- Muslims: Marriage as Incorporation in Cape Muslim Community.' Islam and Christian- Muslim Relations, 15(2004): 349- 364.

Dhami, S. and Sheikh, A. 'The Muslim Family: Predicament and Promise.' Western Journal of Medicine 173 (2000): 352-356.

Grewal, Zareena A. 'Marriage in Colour: Race, Religion and Spouse Selection in four American mosques,' Ethnic and Racial Studies 32 (February 2009): 323- 345.

Hall, Stuart. 'The Question of Cultural Identity.' Modernity and its Future, edited by Stuart Hall, David Held, \& Tom McGrew, 273- 326, Cambridge: Polity Stuart Hall, 1992.

Johnson, Annysa. 'Ahmadiyya Muslims Worship Freely Here, but Persecuted Elsewhere.' Milwaukee Journal, accessed 10 June 2016, http:// www.jsonline.com/ news/ahmadiyya- muslims- worship- freely- herebut- persecuted- elsewhere- b9957553z1-216452141.html.

Kulczycki A and Lobo AP. 'Patterns, Determinants, and Implications of Intermarriage among Arab Americans,' Journal of Marriage and the Family 64 (2002): 202- 210.

Kulczycki A and Lobo AP. 'Continuity and Change in the Arab American Population, 1980- 2006,' Paper presented at the European Population Conference, Barcelona, 9-12 July 2008.

Mohanty, Talpade Chandra. 'Under Western Eyes: Feminist Scholarship and Colonial Discourses.' Feminist Review 30 (1988): 61- 88.

Othman, Enaya. 'Strategies of Recognition and Palestinian Immigrant Women's Cultural Dress: Forging Communities and Negotiating Power Relations,' Journal of New Middle East Studies 5 (2015): 1- 15. Accessed January 12, 2016. http:// www.brismes.ac.uk/ nmes/ archives/ 1447.

Othman, Enaya. 'Arab- American in Milwaukee: History and Assimilation.' Master's Thesis, Department of History, University of Wisconsin, Milwaukee. 1998.

Othman, Enaya. 'The Immigrants to Milwaukee from the Arab World,' Arab and Muslim Women Research and Resource Institute Website, amwrri. Accessed 3 July 2013, http:// amwrri.org/ articles.htm.

Roy, Oliver. Globalized Islam: The Search for a New Ummah. New York: Columbia University Press, 2004.

Said, E. Orientalism. New York: Vintage Books, 1979.

Schwartz, Christine R. and Robert D. Mare. 'Trends in Educational Assortative Marriage from 1940 to 2003.' Demography 42 (2005): 621-646.

Weber, Charlotte. 'Unveiling Scheherazade: Feminist Orientalism in the International Alliance of Women, 19111950,' Feminist Studies, 27 (Spring, 2001): 125- 127.

\section{Notes}

1 Portions of the oral interviews used in this study were conducted as part of a large oral history project that has been taking place since 2010. The project is led by the Arab and Muslim Women's Research and Resource Institute (AMWRRI), a non- profit organization that focuses on collecting the narratives of women from the Arab and Muslim communities in greater Milwaukee region.

2 For more information about these diasporic organizations see Enaya Othman, 'Strategies of Recognition' and Palestinian Immigrant Women's Cultural Dress: Forging Communities and Negotiating Power Relations,' Journal of New Middle East Studies, 5 (2015): 1- 15, accessed 28 February 2016, http:// www.brismes.ac.uk/nmes/archives/1447; Adnan Ahmad Personal Interview. 4 May 1998, Ahmad was an active member of the Arab community in Milwaukee during this period. 
3 Oliver Roy, Globalized Islam: The Search for a New Ummah (New York: Columbia University Press, 2004).

4 See Leila Ahmad, The Veil's Resurgence, from the Middle East to America (New Haven: Yale University Press, 2011).

5 Enaya H. Othman, 'Arab- American in Milwaukee: History and Assimilation' (Master's Thesis, Department of History, University of Wisconsin, Milwaukee, 1998).

6 Waheed al- Deen Ahmed, a Pakistani doctor immigrant who settled in Milwaukee in 1977, was an instrumental figure in establishing the Islamic Society of Milwaukee, ism. He said that the Muslim student organizations and the Doctors Association, which was called 'The Islamic Foundation of Greater Milwaukee,' got together and purchased this center on the South $13^{\text {th }}$ Street and Layton. Waheed alDeen Personal Interview, 20 October 2012.

7 For more information on ism history and activities see their official website http:// www.ismonline.org/

8 There are also other non- Sunni Muslim sects in Milwaukee such as Dar- ul- Hikmah, a Shia Ithna Asheri Muslim religious organization and Masjid Bait- ul Qadir that belong to Ahmadyyia group. For more information see Annysa Johnson, 'Ahmadiyya Muslims Worship Freely Here, but Persecuted Elsewhere,' The Milwaukee Journal Sentinel, 22 July 2013, accessed 10 June 2016, http:// www.jsonline.com/ news/ ahmadiyya- muslims- worship- freely- here- but- persecutedelsewhere-b9957553z1- 216452141.html; see House of Wisdom, Dar- ul- Hikmah for more information about the Shia Muslims in community Milwaukee, http:// www.dar- ul- hikmah.org/

9 Atta, O. Muslims in Milwaukee: A Brief History. ism, Islamic Society of Milwaukee: 25 Years of Service 19822007 (Milwaukee, WI: ism, printed booklet for the 25th anniversary, 2007). Muslim leaders estimate the population to reach 15,000 based on their congregations. However, there are a number of Muslims who are not Mosque goers and these can be estimated at least 5,000 individuals.

10 Othman, 'Arab- American in Milwaukee,' 1.

11 Enaya H. Othman, 'The Immigrants to Milwaukee from the Arab World,' Arab and Muslim Women Research and Resource Institute Website, amwrri. Accessed 3 July 2013, http://amwrri.org/ articles.htm.

12 Othman, 'Arab- American in Milwaukee.'

13 Ibid.

14 Christine R. Schwartz, and Robert D. Mare. 'Trends in Educational Assortative Marriage From 1940 to 2003.' Demography 42 (2005): 621.

15 Ramallah and al- Berieh were the two major large towns that developed into two largest cities since 1990 s. 16 Dhami, S. and Sheikh, A. 'The Muslim Family: predicament and promise,' Western Journal of Medicine, 173(2000): 352- 356.

17 Othman, 'Strategies of Recognition,' 5.

18 Sabreen Sarsour Personal Interview, 10 October 2015.

19 Immigrants from Kuwait are originally Palestinians who fled to the Gulf States after the creation of Israeli State and then to the United States during the Gulf War in 1990-1991.

20 D. Al- Johar, 'Muslim m Marriages in America: Reflecting New Identities.' The Muslim World, 95 (2005): 557.

21 Othman, 1998, 2014.

22 Bisan Audeh Personal Interview, 10 September 2015.

23 Fatima Sameer Personal Interview, 6 April 2016

24 Salama Ahmad Personal Interview, 30 August 2015; Manal Barakat personal interview, 16 September 2015. 25 Zena Adwan Personal Interview, 5 August 2015.

26 Zareena A. Grewal, 'Marriage in Colour,' 339

27 Fatima Sameer personal Interview, 6 April 2016.

28 Stuart Hall, 'The question of cultural identity,' in Modernity and its future, ed. Stuart Hall, David Held, and Tom McGrew (Cambridge: Polity Stuart Hall, 1992), 310

29 Floya Anthias, 'Evaluating 'Diaspora': Beyond Ethnicity?' Sociology 32(1998): 557- 580. 
